\title{
Інституційний механізм інтеграції внутрішньо переміщених осіб
}

\author{
А. В. Дяченко
}

Наџіональна академія державного управління при Президентові Украӥни

УДК [342.72/.73 - 054.73 : 304.4] (477)

DOI: $10.15421 / 15201750$

У статті досліджено побудову інституційного механізму інтеграції осіб, переміщених всередині країни. Проаналізовано діяльність органів державної влади від початку військових дій на Сході країни та обгрунтовано, що інституціональна структура надання послуг ВПО була ускладнена залученням багатьох міністерств та відомств до надання підтримки ВПО без будь-якої справжньої координації між ними.

Зазначено, що основною проблемою інституціональної структури у перші два роки роботи з ВПО, на думку автора, була розрізненість у підході до формування політики. Волонтерські організації, громадянське суспільство та місцеве населення забезпечили активну відповідь на негайні потреби ВПО. У більшості випадків ця відповідь постійно триває. Уряд України вжив низку заходів, щоб допомогти ВПО пережити вимушене переселення, хоча для того, аби вжити усіх заходів, необхідних для стабілізації ситуації, в якій знаходяться ВПО, можливості Державного бюджету є обмеженими.

Показано, що важливим кроком на шляху дотримання забезпечення прав ВПО було створення окремого органу центральної влади - Міністерства з питань тимчасово окупованих територій та внутрішньо переміщених осіб України, одним із основних завдань якого є забезпечення формування і реалізація державної політики у сфері розбудови миру.

Автор доходить висновку, що протягом 2014-2017 рр. в Україні було створено потужний інституціональний механізм інтеграції ВПО. Проте, багато проблем залишаються ще не вирішеними, зокрема, потребує удосконалення координація взаємодії суб'єктів, які забезпечують інтеграцію внутрішньо переміщених осіб в Україні.

Ключові слова: внутрішньо переміщені особи; інтеграція внутрішньо переміщених осіб; державна соціальна політика щодо внутрішньо переміщених осіб; органи державної влади; громадські організації

\section{Institutional mechanism for the integration of internally displaced persons A. V. Diachenko National academy for public administration under the President of Ukraine}

The Article has studied the construction of the institutional mechanism for the integration of persons displaced within the country. The activities of state governmental bodies since the beginning of military actions in the East of the country have been analyzed, and it has been substantiated that the institutional structure for the provision of services to IDPs was complicated by the involvement of many ministries and departments in the support of IDPs without any real coordination between them.

It is pointed out that the main problem with regard to the institutional structure in the first two years of the work with IDPs was, in the author's opinion, the disparity in the approach to policy formation. Volunteering organizations, the civil society and local population ensured the active response to the immediate needs of IDPs. In most cases, this response is constantly ongoing. The Government of Ukraine has taken a number of measures to help IDPs undergoing the forced resettlement, although in order to take all measures necessary to stabilize the situation, in which IDPs are caught, the possibilities of the State Budget are limited.

Цитування даної статті: Дяченко А. В. Інституційний механізм інтеграції внутрішньо переміщених осіб / А. В. Дяченко // Аспекти публічного управління. - 2017. - Т. 5. - № 12. - С. 50-58.

Citation of this article: Diachenko, A.V. (2017). Instytutsiinyi mekhanizm intehratsii vnutrishno peremishchenykh osib [Institutional mechanism for the integration of internally displaced persons]. Public administration aspects, 5 (12), 50-58.

Received: 11.12 .2017

Accepted: 18.12 .2017 
It is shown that the important step to comply with the provision of IDPs' rights was the creation of the separate central authority - the Ministry for Temporary Occupation Territories and Internally Displaced Persons of Ukraine, one of the main tasks of which is to ensure the formation and implementation of the state policy in the field of peacebuilding.

The author comes to the conclusion that within the period of 2014-2017, the powerful institutional mechanism for the integration of IDPs was created in Ukraine. However, many problems still remain unresolved; in particular, the coordination of interacting between entities, which ensure the integration of internally displaced persons in Ukraine, needs to be improved.

Keywords: internally displaced persons; integration of internally displaced persons; state social policy towards internally displaced persons; state governmental bodies; public organizations

\section{Институциональные механизмы интеграции внутренне перемещенных лиц} Дяченко А. В.

Наџиональная академия государственного управления при Президенте Украинь

В статье исследовано построение институционального механизма интеграции лиц, перемещенных внутри страны. Проанализирована деятельность органов государственной власти с начала военных действий на Востоке страны и обосновано, что институциональная структура по предоставлению услуг ВПО была осложнена привлечением многих министерств и ведомств к оказанию поддержки ВПО без всякой настоящей координации между ними.

Отмечено, что основной проблемой институциональной структуры в первые два года работы с ВПО, по мнению автора, была разрозненность в подходе к формированию политики. Волонтерские организации, гражданское общество и местное население обеспечили активный ответ на немедленные потребности ВПО. В большинстве случаев этот ответ постоянно продолжается. Правительство Украины приняло ряд мер, чтобы помочь ВПО пережить вынужденное переселение, хотя для того, чтобы принять все меры, необходимые для стабилизации ситуации, в которой находятся ВПО, возможности государственного бюджета ограничены.

Показано, что важным шагом на пути следования обеспечения прав ВПО было создание отдельного органа центральной власти - Министерства по вопросам временно оккупированных территорий и внутренне перемещенных лиц Украины, одной из основных задач которого является обеспечение формирования и реализации государственной политики в сфере развития мира.

Автор приходит к выводу, что в течение 2014-2017 гг. в Украине был создан мощный институциональный механизм интеграции ВПО. Однако, многие проблемы остаются еще нерешенными, в частности, требует совершенствования координация взаимодействие субъектов, обеспечивающих интеграцию внутренне перемещенных лиц в Украине.

Ключевые слова: внутри перемещенные лица; интеграция внутренне перемещенных лиц; государственная социальная политика в отношении внутренне перемещенных лиц; органы государственной власти; общественные организации

Постановка проблеми. Внаслідок окупації Криму Російською Федерацією і масових порушень прав людини на території Кримської автономії, злочинної діяльності сепаратистських та проросійських терористичних організацій у Донецькій та Луганській областях: убивств, викрадень, катувань, мародерства, грабежів, збройних нападів на військові частини, державні та комунальні установи, а також на приватні помешкання, внаслідок проведення антитерористичної операції українськими силовими структурами у відповідь на злочинні дії терористів і спричинення терористами бойових дій виникла ситуація масової вимушеної міграції з даних територій.

Кількість внутрішньо переміщених осіб (ВПО) з Донецької та Луганської областей, а також АР Крим станом на 20 листопада 2017 року складає 1498158 переселенців або 1221968 сімей і сформувалась унаслідок кількох міграційних хвиль, безпосередньо пов'язаних із періодичністю та інтенсивністю бойових дій.

За таких умов $є$ необхідним термі- 
нове формування інституціонального механізму інтеграції внутрішньо переміщених осіб для забезпечення їх прав i свобод, гарантування безпеки їх життя та здоров'я і створення рівних умов для реалізації їх прав та законних інтересів.

Стан наукових досліджень. Проблеми інтеграції внутрішньо переміщених осіб останнім часом привертають пильну увагу науковців: В. Андерсона, М. Алмаші, А. Артеменка, О. Брайчевської, Ю. Брайчевського, Ю. Дегтяревої, Ш. Шахвали, Я. Пилинського, В. Олефіра, Т. Семигіної, Н. Гусака, С. Трухана, І. Карпової, Р. Свдокименко та ін.

Метою статті $\epsilon$ аналіз інституціонального механізму інтеграції внутрішньо переміщених осіб в Україні.

Виклад основного матеріалу. Першими органами державної влади, які почали діяльність щодо ВПО, були навесні 2014 року Державна служба України 3 надзвичайних ситуацій (ДСНС) та Мiністерство соціальної політики (МСП), зокрема Управління соціального захисту населення та Пенсійний фонд України на центральному, обласному і районному рівнях, які почали відслідковувати кількість ВПО, що звернулись за допомогою до державних органів.

11 червня 2014 року Кабінет міністрів України затвердив План заходів, який дозволив ДСНС розпочати першу офіційну реєстрацію ВПО [5].

1 жовтня 2014 року Кабмін затвердив Постанову № 509, відповідно до якої було створено єдину систему реєстрації, яку веде МСП, із делегованими повноваженнями щодо взяття на облік та здійснення грошових виплат районним управлінням соціального захисту населення [7].

Як зазначено в даному документі, неможливо заздалегідь спланувати стратегію дій уряду щодо вимушених переселенців. Це можна зробити лише після того, «як подія відбулась». Ми не підтримуємо точку зору деяких організацій, наприклад, Інституту Брукінгса, що «навіть рік потому, державне реагування було недостатнім, уряд не був готовий, i від- повідь в значній мірі залежала від волонтерів та гуманітарних організацій» [9]. Уряд України використовував інституціі, які були йому доступні через МСП та ДСНС, щоб допомогти тим, хто постраждав у результаті анексії Криму та конфлікту на Донбасі, настільки, наскільки це було можливо в той дуже неспокійний період, який відзначився не лише анексією та військовим конфліктом, а й зміною Президента, виконавчої та законодавчої гілок влади.

Служба безпеки України (СБУ) здійснювала контроль за базами даних ВПО, у зв'язку з чим було рекомендовано вибіркове припинення виплат.

Інституціональна структура надання послуг ВПО була ускладнена залученням багатьох міністерств та відомств до надання підтримки ВПО без будь-якої справжньої координації між ними.

Для допомоги переселенцям Уряд України створив Міжвідомчий координаційний штаб, до якого увійшли представники 15 міністерств і відомств. Створено інформаційні ресурси, розроблено і розповсюджуються серед колишніх мешканців Донбасу та Криму «дорожні карти» 3 чітким алгоритмом дій, покликані допомогти ВПО ознайомитися $з$ їхніми правами і можливостями, які надає держава.

Інші державні органи загалом ефективно відреагували на кризу. Центр зайнятості активно підтримує спроби ВПО у пошуку роботи, створивши окремі департаменти, спрямовані виключно на надання допомоги ВПО у пошуку роботи. Уряд України готовий дотувати зайнятість ВПО протягом одного року. Вживаються заходи, щоб спонукати роботодавців скористатися цим [4]. Із метою посилення соціального захисту внутрішньо переміщених осіб та підвищення зацікавленості роботодавців у їх працевлаштуванні державною службою зайнятості забезпечено реалізацію заходів сприяння зайнятості ВПО, передбачених статтею 24-1 Закону України «Про зайнятість населення» [6], щодо компенсації роботодавцям витрати на оплату праці за працевлаштованих безробітних із числа внутрішньо переміще- 
них осіб, а у разі потреби - компенсації витрат на їх перепідготовку чи підвищення кваліфікації. Також зареєстрованим безробітним із числа внутрішньо переміщених осіб здійснюється компенсація фактичних витрат на переїзд до іншої адміністративно-територіальної одиниці місця працевлаштування та витрати для проходження медичного огляду, якщо це необхідно для працевлаштування.

Протягом січня-травня 2016 року працевлаштовано 696 внутрішньо переміщених осіб із числа безробітних із компенсацією роботодавцю витрат на оплату праці, 12 ВПО з числа безробітних отримали компенсацію витрат для проходження медогляду [2].

Міністерство освіти і науки України сприяло безперешкодному доступу до освіти дітей ВПО. За результатами опитування самих ВПО, в деяких населених пунктах відбулася позитивна дискримінація під час влаштування дітей у дошкільні заклади - пріоритет віддавався вступу дітей ВПО в дитячий сад за рахунок місцевих жителів. 3 іншого боку, деякі ВПО свідчать, що для них було проблемою влаштувати своїх дітей у дитячі садки. Слід зазначити, що існує загальний брак місць у дитячих садках, навіть ще до конфлікту дитячі садки мали місця для менш ніж 60\% дітей відповідного віку [4].

Для учнів молодшої та загальної середньої шкіл не було жодних проблем із доступом до освіти. В переважній більшості випадків діти ВПО на початковому та середньому рівні шкільної освіти розміщувались у рамках існуючої структури класів.

Були певні питання стосовно вищої освіти. Для тих, хто проживає на неконтрольованій Урядом території (НКУТ), можливо отримати український атестат про шкільну освіту, необхідний для вступу до ВНЗ України, пройшовши навчання за українською програмою через Інтернет (або у школах для дистанційного навчання або у школах для екстернів). Однак, для складання $3 \mathrm{HO}$, яке є еквівалентом вступного екзамену до ВН3, потрібно особисто приїхати на контр- ольовану Урядом територію (КУТ) (при цьому пов'язані з таким приїздом видатки фінансуються за рахунок Державного бюджету) [4]. МОН надавало фінансову допомогу тим ВПО, які бажають отримувати вищу освіту, зокрема фінансування гуртожитків, безкоштовних підручників i т. ін. Мінфін відхилив запропонований план фінансування 3 фінансових міркувань, проте план фінансування ВПО із Криму був затверджений.

Міністерство охорони здоров'я докладало певних зусиль щодо забезпечення доступу для отримання медичної допомоги ВПО, проте, за оцінками міжнародних експертів, ситуація 3 охороною здоров'я в областях, які знаходяться найближче до лінії розмежування, $\epsilon$ в найкращому випадку дуже напруженою, а в найгіршому - кризовою [4]. I це проблема не лише для ВПО, а й для усіх громадян, які живуть у цих областях, оскільки вони користуються тією ж самою системою охорони здоров’я. Однак, для ВПО, чия фінансова ситуація є критичною, особливо для людей похилого віку, яким не виплачуються ані соціальні виплати, ані пенсії, ситуація $\epsilon$ навіть ще більш критичною, оскільки для них є обмеженим доступ до базових потреб, таких як харчування, медикаменти та засоби гігієни. Представники Всесвітньої організації охорони здоров’я (ВОО3) занепокоєні ситуацією на НКУТ, особливо повільним прогресом в області гуманітарного права i труднощами у поставці найважливіших медикаментів за лінію розмежування.

На думку міжнародних експертів [4], стан здоров'я людей погіршився у зв'язку 3 обмеженим доступом до доступної медичної допомоги, і у зв'язку з тим, що ті лікувальні установи, які знаходяться на КУТ, наразі мають обслуговувати як місцеве населення, що проживало у цих районах ще до конфлікту, так і тих ВПО, які змушені були переселитись із НКУТ.

Як зазначалось вище, конфлікт також спричиняє психологічний стрес для населення, і соціальні працівники Мінсоцполітики намагаються щосили впоратись із цією ситуацією. 
Ми підтримуємо думку експертів [4], які вважають ситуацію з сектором охорони здоров'я на Донбасі важливим питанням, що потребує негайного вирішення. За наявними даними, під час конфлікту число лікарів у Луганській області скоротилося в 7 разів, а в Донецькій - у 4 рази. Амбулаторно-лікарняна мережа цього регіону зменшилась в 2-4 рази. Транспортна логістика екстреної медичної допомоги була повністю порушена через скорочення числа медичних установ. Хоча більшість скорочення обслуговування відбувається на НКУТ, це має наслідки для КУТ, оскільки така ситуація змушує людей шукати допомоги у медичних установах за лінією розмежування, які вже й без того знаходяться під значним тиском. У тій же статті йдеться про серйозну загрозу спалахів інфекційних захворювань та епідемій [8].

Одна 3 основних проблем, яка стосується сектору охорони здоров'я, це те, що на КУТ Донецької та Луганської областей не залишилось лікарень третього рівня, оскільки вони фізично розташовані у Донецьку та Луганську, які не контролюються українським Урядом. Це створює проблеми для людей, що потребують медичного лікування високого рівня, оскільки лікувальні заклади другого рівня не в змозі задовольнити їхні потреби.

Отже, основною проблемою інституціональної структури у перші два роки роботи з ВПО, на нашу думку, була розрізненість у підході до формування політики. Волонтерські організації, громадянське суспільство та місцеве населення забезпечили активну відповідь на негайні потреби ВПО. У більшості випадків ця відповідь триває постійно. Уряд України вжив низку заходів, щоб допомогти ВПО пережити вимушене переселення, хоча для того, аби вжити усіх заходів, необхідних для стабілізації ситуації, в якій знаходяться ВПО, можливості Державного бюджету є обмеженими. Міжнародні експерти оцінили діяльність інституціональної структури при уряді Яценюка за критерієм результативності - як менш ніж достатню, оскільки було значне ду- блювання діяльності та відсутній загальний керівний центр із даних питань; за критерієм відповідності - як достатню на операційному рівні [4]. Послуги надавались працівниками державних органів, що співчували ВПО та намагались усіляко допомогти їм у межах своїх можливостей. За критерієм впливу - це те, що вона до певної міри допомогла ВПО у процесі прилаштування до нового життя. Працівники державних органів, задіяних у цьому процесі, мали діяти відповідно до державної політики. Низка проблем із державною політикою призвела до інституціональних проблем, але якби ці проблеми були вирішені, інституціональна структура була б більш спроможною надавати такий рівень послуг, на очікування та отримання якого ВПО мають право. Тому за критерієм сталості структуру оцінили як нежиттєздатну. Існує велике навантаження на працівників, які працюють 3 ВПО, тому, щоб уникнути проблем із наданням послуг не лише ВПО, а й усім українцям, потрібно буде забезпечення додатковими ресурсами.

Активним суб'єктом інтеграції ВПО є Комітет Верховної Ради України з питань прав людини, національних меншин та міжнаціональних відносин.

Важливим кроком на шляху дотримання забезпечення прав ВПО було створення окремого органу центральної влади - Постановою Кабінету Міністрів України від 8 червня 2016 р. № 376 Уряд визначив повноваження Міністерства 3 питань тимчасово окупованих територій та внутрішньо переміщених осіб України. Передбачено, що одним із основних завдань новоствореного Міністерства є забезпечення формування та реалізації державної політики у сфері розбудови миру [3]. Також документом визначаються єдині організаційні й методичні підходи у вирішенні питань щодо забезпечення формування і реалізації державної політики у сфері розбудови миру, координації діяльності з надання гуманітарної допомоги, сприяння, у межах компетенції, в реалізації комплексу заходів, спрямованих на зменшення соціального, економіч- 
ного та екологічного впливу вибухонебезпечних предметів на життя та діяльність населення [1].

Основною діяльністю Міністерства буде впровадження положень документу «Оцінка відновлення та розбудови миру в Україні - Аналіз впливу кризи та потреб на Східній Україні».

Щоб проведення політики було ефективним, ця структура повинна мати:

- регіональні відділення 3 компетентним персоналом і відповідним бюджетом;

- розподіл обов'язків між центральними, регіональними та місцевими органами державної влади, органами місцевого самоврядування і громадськими та неурядовими організаціями, що займаються проблемами інтеграції ВПО;

- надійну й адекватну інформаційну систему, включаючи науково-дослідне забезпечення;

- нормативно-правову базу 3 питань інтеграції ВПО;

- механізм контролю за реалізацією законодавства на практиці та витрачанням коштів бюджету;

- технічні можливості для здійснення обліку ВПО;

- систему підготовки кваліфікованих кадрів і керівників в галузі управління процесами інтеграції ВПО.

В умовах децентралізації великі повноваження на разі передаються місцевим органам влади та органам влади громад. Це позитивно вплине на ВПО. Наприклад, раніше для реєстрації як ВПО людям необхідно було спочатку звернутись в органи соцзахисту, а потім у ДМС. У ДМС на їхню довідку ВПО ставилась печатка. Аналогічний процес застосовується для відновлення призупиненої пенciї або соціальної допомоги. Однак, починаючи 3 середини квітня 2016 р. ДМС більше не відповідає за реєстрацію. Відповідальність за реєстрацію лежить тепер на органах місцевого самоврядування. Моніторинг ефективності та дієвості місцевих органів влади у цій частині процесу буде мати важливе значення.

Систему органів законодавчої та ви- конавчої влади, органів місцевого самоврядування доповнюють неурядові та громадські організації самих ВПО, міжнародні організації та благодійні фонди, зокрема Управління Верховного комісаpa $\mathrm{OOH}$ із прав людини (УВКПЛ), Офіс OОН з координації гуманітарних питань (ОКГП), Управління Верховного Комісара ООН у справах біженців (УВКБ) та Координатор ООН з гуманітарних питань, Міжнародна організація 3 міграції (МОМ), Міжнародний Комітет Червоного Хреста (МКЧХ) і Рада Європи (РС), Свропейський Союз через представництво в Україні, Міжнародні агентства 3 координації технічної допомоги, загальнонаціональні, місцеві та міжнародні громадські організації.

До міжнародних організацій, які надають допомогу ВПО у надзвичайних ситуаціях, входять ЄС, ООН (УВКБ, ВПП (Всесвітня продовольча програма - від англ. WFP), ФАО (Продовольча та сільськогосподарська програма ООН - від англ. Food and Agriculture Organization), ЮНІСЕФ, ВООЗ, ПРООН), МОМ, Червоний Хрест (МКЧХ і МФЧХіПМ), Данська рада у справах біженців, Польський центр міжнародної допомоги, «Людина в біді» (People in Need), «Лікарі світу» (Medicins дю Монд), «Врятуймо дітей» (Save the Children) та інші. До тих організацій, які несуть основну відповідальність за надання консультацій у сфері Міжнародного гуманітарного права, належать УВКБ ООН, ОКГП ООН, ООН та МКЧХ.

Загалом, 27 міжнародних організацій присутні в Україні, які разом із українськими ГО складають близько 147 організацій, включаючи їхні обласні представництва, що працюють безпосередньо 3 ВПО.

Діяльність цих структур теж потребує узгодження. Уряд України має нагадати усім донорам, які надають допомогу ВПО, що Керівні принципи ООН стосовно комп'ютеризованих файлів персональних даних від 1990 року зі змінами та доповненнями мають пріоритет над українським законодавством про захист 
персональних даних та мають заохочувати співпрацю між донорами щодо обміну списками отримувачів допомоги 3 тим, щоб звести до мінімуму випадки, коли одна ВПО отримує численні пакети 3 допомогою від різних донорів [4].

При тому, що п’ять різних державних відомств займаються вирішенням питань ВПО, у жодного 3 агентств ООН не має жодного партнера.

Основні міжнародні організації, присутні в Україні, мають великий досвід роботи в надзвичайних ситуаціях i peaгування на кризи, пов'язані 3 біженцями та вимушеними переселенцями, у багатьох частинах світу протягом десятиліть. Що стосується реагування на надзвичайні ситуації на початковому етапі - надання притулку, розподіл продуктів харчування, медикаментів, одягу і т. і. - ця допомога, безсумнівно, була відповідною, ефективною i надавалась оперативно. Ця допомога мала б істотний вплив на найбільш уразливі групи ВПО, якщо припустити, що найбільш уразливі стали бенефіціаріями цієї допомоги.

Зовсім недавно, на додаток або замість розподілу вище зазначеної допомоги, з'явилась тенденція переходу деяких ГО на розподіл готівкових коштів, таким чином ГО визнають, що потреби ВПО можуть відрізнятися від однієі сім’ї до іншої, і забезпечують гнучкість у задоволенні цих потреб.

За допомогою об'єднання ресурсів, що становлять приблизно 15\% грошової допомоги, яку надає уряд України ВПО, міжнародні ГО, як правило, роблять скоріше нерегулярні, а не місячні розподіли допомоги. Наприклад, у 2015 році МКЧХ розподілив 355000 харчових наборів і 371000 гігієнічних наборів. Як i належить гуманітарним операціям, у деяких випадках гуманітарна допомога була спрямована не лише на ВПО. Вразливі групи населення без статусу ВПО, які проживають поруч ліній розмежування або насправді на неконтрольованих територіях, також включені у надання допомоги [4].

Становлення неурядових організацій переселенців у всіх країнах процес тривалий i болючий, тому що необхідною умовою для співпраці 3 урядовими органами є завоювання довіри та авторитету добросовісною і професійною діяльністю. Тільки після певного періоду часу (не менше п'яти років) вдається встановити, які з організацій, створених самими переселенцями, заслуговують довіри держави та, відповідно, права на використання бюджетних коштів.

Головна принципова відмінність роботи громадських і неурядових організацій полягає в тому, що вони діють у безпосередньому контакті 3 місцевим населенням.

Український фонд соціальних інвестицій (УФСІ) $€$ неприбутковою організацією, що створена 3 метою підтримки найменш соціально захищених верств населення, а також ініціатив територіальних громад і громадських організацій.

Соціальна ефективність роботи 3 населенням на місцях досить велика. Вона дозволяє підвищувати ступінь інформованості ВПО, знижувати напруженість у суспільстві, здійснювати додатковий контроль за дотриманням прав ВПО. У той час, як недостатня увага до роботи 3 населенням, навпаки, провокує розростання конфліктних ситуацій, веде до формування негативної оцінки діяльності державних органів і політики держави щодо ВПО в цілому.

Висновок. Протягом 2014-2017 рр. в Україні було створено потужний інституціональний механізм інтеграції ВПО. Проте, багато проблем залишаються ще не вирішеними, зокрема, потребує удосконалення координація взаємодії суб'єктів, які забезпечують інтеграцію внутрішньо переміщених осіб в Україні. 


\section{БІБЛІОГРАФІЧНІ ПОСИЛАННЯ:}

1. Деякі питання Міністерства з питань тимчасово окупованих територій та внутрішньо переміщених осіб: Постанова Кабінету Міністрів України від 8 червня 2016 р. № 376. - Режим доступу: http://zakon0.rada.gov.ua/laws/show/376-2016-\%D0\%BF.

2. Звіт про стан виконання у II кварталі 2016 року заходів, передбачених Комплексною державною програмою щодо підтримки, соціальної адаптації та реінтеграції громадян України, які переселилися з тимчасово окупованої території України та районів проведення антитерористичної операції в інші регіони України, на період до 2017 року. - Режим доступу: http:// www.mlsp.gov.ua/labour/control/uk/publish/category?cat_id=169302.

3. Ключові засади державної політики у сфері забезпечення прав і свобод внутрішньо переміщених осіб: Аналітична записка // Національний інститут стратегічних досліджень. - Режим доступу: http://www.niss.gov.ua/articles/2375/.

4. Оцінка комплексу заходів, які вживає уряд України щодо надання соціальних послуг внутрішньо переміщеним особам (ВПО): Остаточний звіт про результати оцінки (16 червня 2016 року) / Експерти: Грег МакТаггарт, Майкл Стоун. - Режим доступу: http:/www.msp.gov.ua/ news/13403.html.

5. Питання соціального забезпечення громадян України, які переміщуються з тимчасово окупованої території та районів проведення антитерористичної операції : Розпорядження КМУ № 588-р від 11 червня 2014 року. - Режим доступу: http://zakon2.rada.gov.ua/laws/show/5882014-\%D1\%80.

6. Про зайнятість населення : Закон України від 05.07.2012 № 5067-VI. - Режим доступу: http://zakon2.rada.gov.ua/laws/show/5067-17.

7. Про облік внутрішньо переміщених осіб: постанова Кабінету Міністрів України від 1 жовтня 2014 р. № 509. - Режим доступу: http://zakon2.rada.gov.ua/laws/show/509-2014-\%D0\%BF 8. Public and international organizations are joining forces to address the health problems of Donbas and IDPs. - Retrieved from: http://restoring-donbass.com/en/news/1211-public-and-internationalorganizations-are-joining-forces-to-address-the-health-problems-of-donbas-and-idps/.

9. The Mounting Human Cost of Ukraine's Conflict. - Retrieved from: http://www.hias.org/ mounting-human-cost-ukraines-conflict.

10. Ukraine // USAID. - Retrieved from: https://www.usaid.gov/crisis/ukraine.

\section{REFERENCES:}

1. Deiaki pytannia Ministerstva z pytan tymchasovo okupovanykh terytorii ta vnutrishno peremishchenykh osib: Postanova Kabinetu Ministriv Ukrainy vid 8 chervnia 2016 r. № 376 [Some issues of the Ministry for Temporary Occupied Territories and Internally Displaced Persons: Resolution of the Cabinet of Ministers of Ukraine from june 8, 2016 № 3767. Retrieved from: http:// zakon0.rada.gov.ua/laws/show/376-2016-\%D0\%BF [in Ukrainian].

2. Zvit pro stan vykonannia u II kvartali 2016 roku zakhodiv, peredbachenykh Kompleksnoiu derzhavnoiu prohramoiu shchodo pidtrymky, sotsialnoi adaptatsii ta reintehratsii hromadian Ukrainy, yaki pereselylysia z tymchasovo okupovanoi terytorii Ukrainy ta raioniv provedennia antyterorystychnoi operatsii $v$ inshi rehiony Ukrainy, na period do 2017 roku [Report on the state of implementation in the second quarter of 2016 of the measures envisioned by the Integrated State Program for Support, Social Adaptation and Reintegration of Ukrainian Citizens who moved from temporarily occupied territory of Ukraine and areas of anti-terrorist operation to other regions of Ukraine until 2017]. Retrieved from: http://www.mlsp.gov.ua/labour/control/uk/publish/ category?cat id $=169302$ [in Ukrainian].

3. Kliuchovi zasady derzhavnoi polityky u sferi zabezpechennia prav i svobod vnutrishno peremishchenykh osib: Analitychna zapyska [Key Principles of State Policy in the Field of the Protection of the Rights and Freedoms of Internally Displaced Persons: Analytical Note]. National Institute for Strategic Studies. Retrieved from: http://www.niss.gov.ua/articles/2375/ [in Ukrainian]. 4. Otsinka kompleksu zakhodiv, yaki vzhyvaie uriad Ukrainy shchodo nadannia sotsialnykh posluh vnutrishno peremishchenym osobam (VPO): Ostatochnyi zvit pro rezultaty otsinky [Assessment of the measures taken by the Government of Ukraine to provide social services to internally displaced 
persons (VPO): Final evaluation report]. MakTahhart, G., \& Stoun, M. (Exp.). (2016). Retrieved from: http://www.msp.gov.ua/news/13403.html [in Ukrainian].

5. Pytannia sotsialnoho zabezpechennia hromadian Ukrainy, yaki peremishchuiutsia z tymchasovo okupovanoi terytorii ta raioniv provedennia antyterorystychnoi operatsii: Rozporiadzhennia KMU № 588-r vid 11 chervnia 2014 roku [Questions of social security of Ukrainian citizens moving from temporarily occupied territory and areas of anti-terrorist operation: CMU Decree № 588-r from June 11, 2014]. Retrieved from: http://zakon2.rada.gov.ua/laws/show/588-2014-\%D1\%80 [in Ukrainian].

6. Pro zainiatist naselennia: Zakon Ukrainy vid 05.07.2012 № 5067-VI [On Employment of the Population: Law of Ukraine from 05.07.2012 № 5067-VI]. Retrieved from: http://zakon2.rada.gov. ua/laws/show/5067-17 [in Ukrainian].

7. Pro oblik vnutrishno peremishchenykh osib: postanova Kabinetu Ministriv Ukrainy vid 1 zhovtnia 2014 r. № 509 [On the registration of internally displaced persons: the Resolution of the Cabinet of Ministers of Ukraine from October 1, 2014 № 509]. Retrieved from: http://zakon2.rada.gov.ua/laws/ show/509-2014-\%D0\%BF [in Ukrainian].

8. Public and international organizations are joining forces to address the health problems of Donbas and IDPs. Retrieved from: http://restoring-donbass.com/en/news/1211-public-and-internationalorganizations-are-joining-forces-to-address-the-health-problems-of-donbas-and-idps/.

9. The Mounting Human Cost of Ukraine's Conflict. Retrieved from: http://www.hias.org/mountinghuman-cost-ukraines-conflict.

10. Ukraine // USAID. Retrieved from: https://www.usaid.gov/crisis/ukraine.

Дяченко Андрій Васильович - аспірант

Національна академія державного управління при Президентові України

Адреса: 03057, м. Київ, вул.Антона Цедіка, 20

Email: general@academy.gov.ua

Diachenko Andriy V. - Post-Graduate Student

National Academy of Public Administration under the President of Ukraine

Address: 20, Antona Tsedika str., Kyiv, 03057, Ukraine

Email:general@academy.gov.ua 